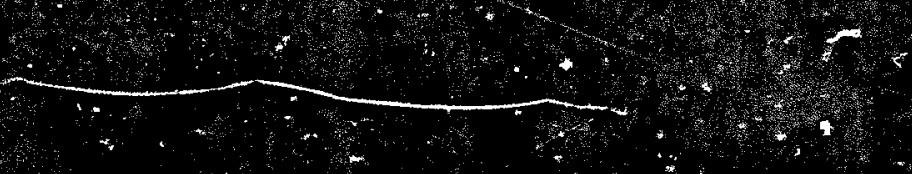
$(2+3)$

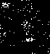

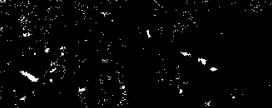
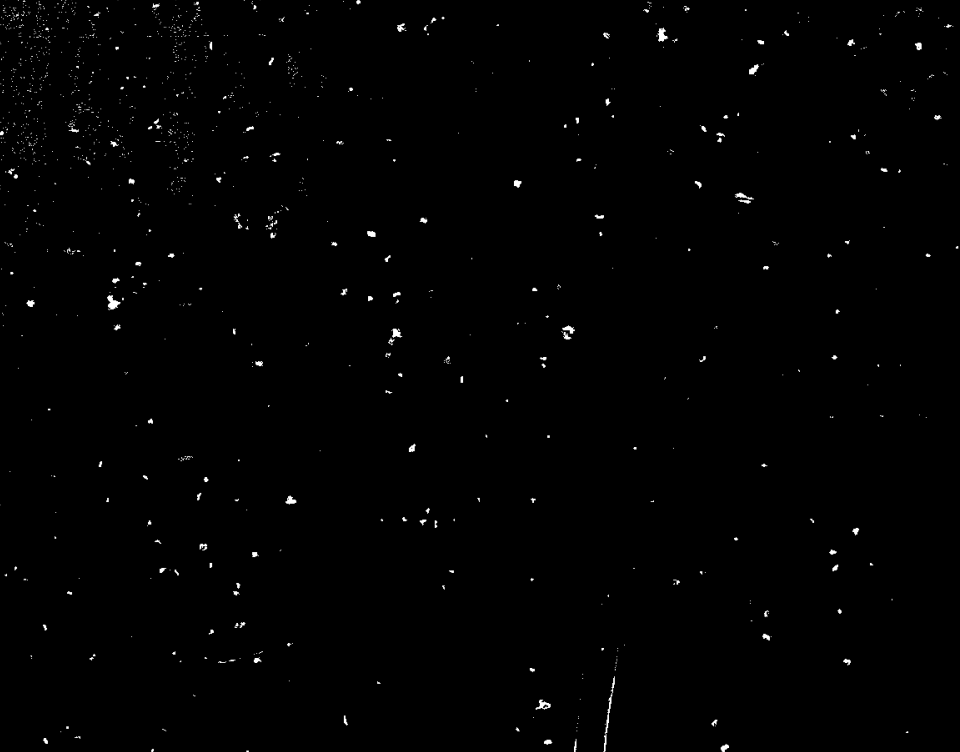
This redort was prepsed as an sccount of work sponsored by an ugencer of the Uniwd Stoted Government

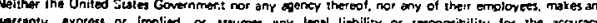

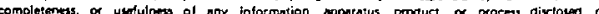

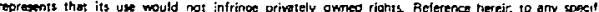

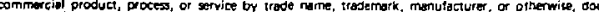

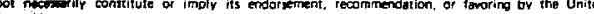

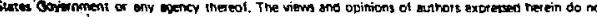

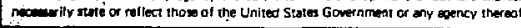

LA-9449-MS

(ISPO-176)

UC-15

Issued: August 1982

LA- $-9449-$ HS

DE83 000467

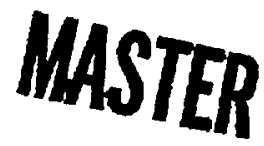

\title{
Field Test and Evaluation of the \\ Passive Neutron Coincidence Collar for Prototype Fast Reactor Fuel Subassemblies
}

\author{
NOTIEE - \\ H. O. Menlove \\ A. Keddar* \\ PORTIONS OF THLS REPORT ARE JLLEDL' \\ It has been reficalieswi from the bext \\ arailsbie copy is permit the wroulest \\ possible avallability.
}

Participants

H. O. Menlove, Los Alamos National Laboratory

A. Keddar, J. Craig, and J. Lukavesky, IAEA, Vienna, AUSTRIA

1. Douglas and H. Mellon, BNFL Windscale Works, Seascale 333, UNITED KINGDOM

H. Green, UK-AEA .11 Charies II Street, London SW1Y 4QP, ENGLAND

"International Atomic Énergy Agency, P. O. Box 100, A 1400, Vienna, AUSTRIA.
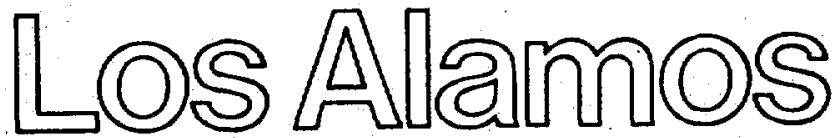

Los Alamos National Laboratory Los Alamos, New Mexico 87545 


\section{CONTENTS}

\section{ABSTRACT}

\section{INTRODUCTION}

II. DESCRIPTION OF THE PNCC ............. 2

A. Detector Head .............. 2

B. Electronics .............. 4

C. Detector Cart ................ 4

III. DESCRIPTION OF FUEL ASSEMBLIES ..........4 4

IV. EXPERIMENTAL PROCEDURES ........... 5

A. Physical Setup ............ 5

B. Measurement Steps ........... 5

1. Initial Check-out ........... 6

2. Routine Operation ......... 7

C. Nonroutine-Active Mode Fissile Attribute .....7 7

D. Handling and Transfer Times ......... 7

v. TEST RESULTS ................ 8

A. Electrical Noise and Neutron Backgrounds . . . . . 8

B. Passive Results-- ${ }^{240}$ Pu-Effective Mass ...... 8

C. Active Results--Plutonium Fissile ....... 9

D. Radial and End Effect Results ......... 10

E. In-Plant Precision and Stability ........ 10

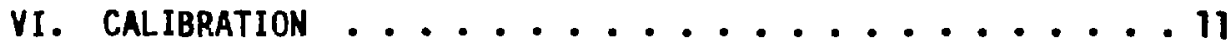

A. Plutoniun-240 Effective Mass ..........11

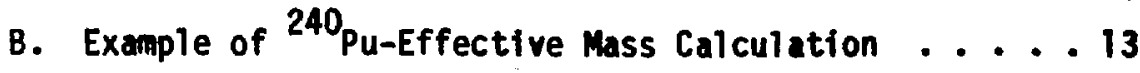

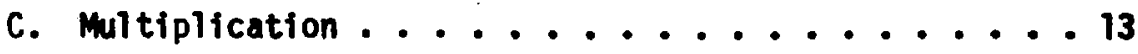


VII. CONCLUSIONS AND RECOMHENDATIONS ......... 14

A. Accuracy for ${ }^{240}$ Pu-Effective Mass ....... 14

B. Neutron Backgrounds and Electrical Noise ...... 14

C. Precision and Stability ........... 14

D. Accuracy for ${ }^{239} \mathrm{Pu}+{ }^{241} \mathrm{Pu} \ldots \ldots 14$

E. Recommendations ............ 15

APPENDIX A: DATA COLLECTION AND STATISTICAL ANALYSES PROGRAM USING THE HP-97 CALCULATOR ......... 16

APPENDIX B: PASSIVE/ACTIVE MODE ASSAY . . . . . . 20

REFERENCES ................. 22 
FIELD TEST AND EYALUATION OF THE PASSIVE NEUTRON COINCIDENCE COLLAR FOR PROTOTYPE FAST REACTOR FUEL SUBASSEMBLIES

\author{
by
}

H. O. Menlove and A. Keddar

\begin{abstract}
The passive neutron Coincidence Collar, which was developed for the verification of plutonium content in fast reactor iuel subassemblies, has been field tested using prototype fast reactor fuel. For passive applications, the system measures the $240 \mathrm{pu}$-effective mass from the spontaneous fission rate, and in addition, a self-interrogation technique is used to determine the fissile content in the subassembly. Both the passive and active modes were evaluated at the Windscale Works in the United Kingdom. The results of the tests gave a standard deviation $0.75 \%$ for the passive count and $3-7 \%$ for the active measurement for a $1000-s$ counting time. The unit will be used in the future for the verification of plutonium in fresh fuel assemblies.
\end{abstract}

\title{
I. INTRODUCTION
}

The passive neutron Coincidence Collar. (PMCC) has been developed at Los Alamos ${ }^{7}$ for verifying the plutoniun content in fast reactor fuel subassenblies. The PNCC is closely related to the active neutron coincidence collar. differing in that fourth detector bank replaced the hili neutron source for the passive assay of subassemblites containing plutonium. In addition, twe counting efficiency and die-away time were modified to accommode the hish plutonium content in the prototype fast reactor (PFR) subassablites. A classIII PMCC has been supplied to the IAEA under Task A-73 for test and malantiont: 
This unit was checked out in Vienna before going to the United Kingdom for field tests.

The passive assay method employs the same method as used with the HighLevel Coincidence Counter (HLNCC); ${ }^{2}$ that is, passive neutron coincidence counting of neutrons from the spontaneous fission of ${ }^{240}$ Pu-effective. In addition to the normal passive measurement, the passive neutrons can self-interrogate the assembly by reflecting them back into the assembly with the $\mathrm{CH}_{2}$ body of the PNCC. These reflected neutrons then induce fission reactions in the fissile component of the fuel. To determine the neutron fraction resulting from the reflection process, the albedo of the boundary surrounding the fuel assembly is changed by inserting or removing a cadmium liner. The combination of the passive ${ }^{240} \mathrm{Pu}$-effective measurement and the active fissile measurement gives the total plutonium content.

This report sumarizes the results of the field test and evaluation of the PNCC for PFR subassemblies performed at the Windscale Works, Seascale, United Kingdom, from March 8-11, 1982. Both the passive and active modes were tested, as were the corresponding software programs for the Hewlett-Packard $\mathbf{H P}-97$. The equipment was demonstrated to the staffs from the International Atomic Energy Agency (IAEA), Windscale, and the Atomic Energy Agency of the United Kingdom (AEA-UK).

\section{DESCRIPTION OF THE.PNCC}

\section{A. Detector Head}

The PNCC detector head is shown schematically in Fig. 1 . Four groups of

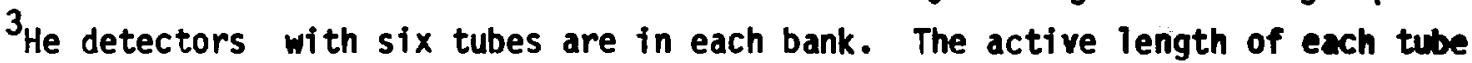
is $33 \mathrm{~cm}$, the overall unit height is $45 \mathrm{~cm}$, and the weight is approximately $27 \mathrm{~kg}$. Removable cadmiun liners attach to the inside of the sample cavity with screws for quick removals.

The PNCC has been designed with the same basic dimensions and specifications as the standard Coincidence Collar for interchangeability of parts. Figure 2 is a photograph of the PACC, and Fig. 3 shows the complete unit, including the electronics and cart.

Reference 1 details the PMCC design and modifications for high counting rate applications: 

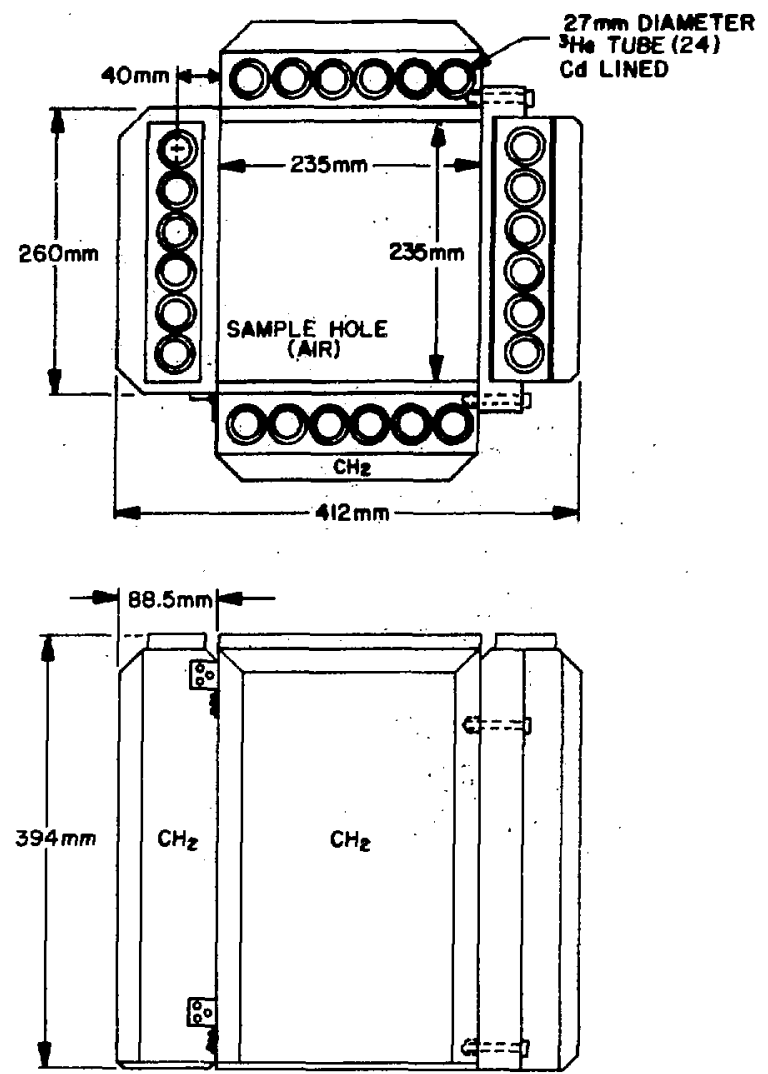

Fig. 2.

The PNCC detector head, which was placed sideways for use in the field tests at Windscale.
Fig. 1 .

Passive neutron Coincidence Collar (PNCC) used for measuring PFR subassemblies.

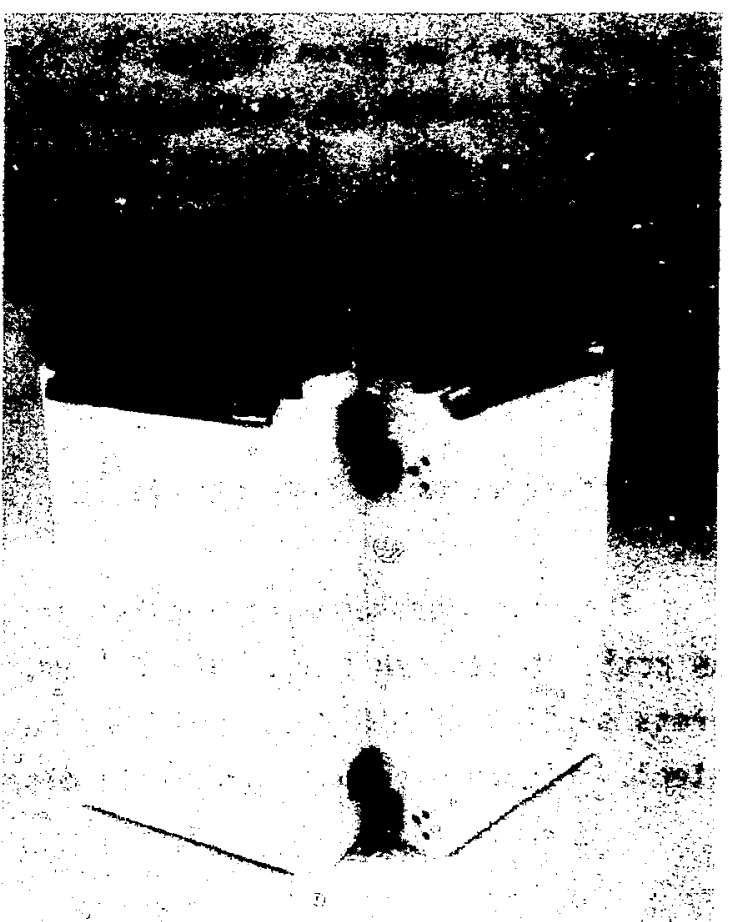




\section{B. Electronics}

The electronic components include the shift-register coincidence package (HEC-100), preamplifiers, and the HP-97 calculator for data reduction and printout. These components are identical to that used with the HLNCC.

The recommended settings are as follows.

$$
\begin{aligned}
\text { High voltage }= & 7.5(1500 \mathrm{~V}) \\
\text { Disc } & 3.0(1.5 \mathrm{~V}) \\
\text { Gate } & 32 \mu \mathrm{s} \\
\text { Time } & \text { desired run time } \\
& (100-\text { to } 1000-\mathrm{s} \text { re- } \\
& \text { cycle })
\end{aligned}
$$

\section{Detector Cart}

For normal use at the reactor site, the fuel assemblies will be stored vertically, and the PNCC will be on its cart as shown in Fig. 3. The unit can be rolled up to the assembly with the door open. Wher the assembly in its storage canister is inside the detector, the door is closed and the measurement can begin.

For the present tests at Windscale, the cart was not. used because it was necessary to measure the subassemblies horizontally.

\section{DESCRIPTION OF FUEL ASSEMBLIES}

The PFR subassemblies consist of a hexagonal array of 325 fuel pins with an active plutonium length of $91.4 \mathrm{~cm}$. The distance from flat to flat for the cross section is $215.2 \mathrm{~cm}$, and the hexagonal can is of 3.2-mm-thick stainless steel. Figure 4 shows a partially disassembled PFR fuel subassembly. 
The MOX in the LMFBR fuel pins consists of natural $\mathrm{UO}_{2}$ mixed with $\mathrm{PuO}_{2}$, which has $222 \% 240 \mathrm{Pu}$. The fue assemblies supplied by the facility for the test and evaluation are listed in Table I, together with the plutonium isotopic content. The plutonium masses of individual fuel subassemblies ranged up to $14.9 \mathrm{~kg}$ and the $240 \mathrm{pu}$-effective mass up to $3.5 \mathrm{~kg}$. We were especially fortunate to obtain the partialiy loaded assemblies as listed in Table I, so we could extend the calibration curve from the 100-pin region up to 325 pins.

\section{EXPERIMENTAL PROCEDURES}

A. Physical Setup

The measurements were performed in the building at Windscale that is

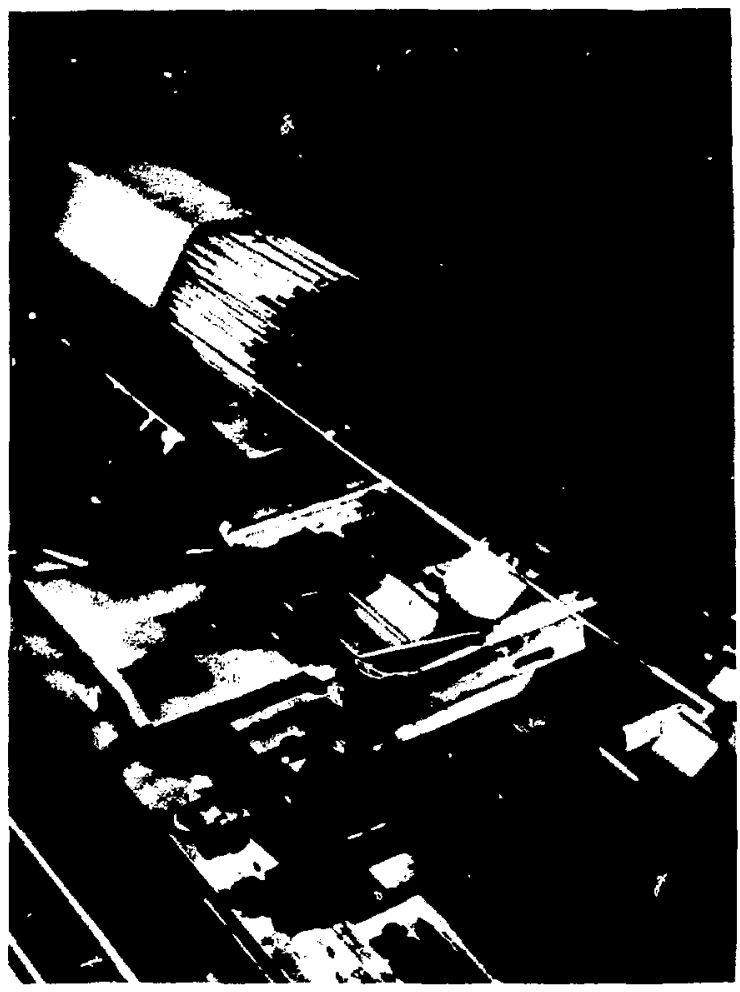

Fig. 4. Partially disassembled PFR fuel subassembly at the reprocessing facility. normally used for fuel pin loading into the subassemblies. In this building, the subassemblies are stored and moved horizontally by the overhead crane. To accommodate this restraint, the PNCC was operated horizontally and the detector cart was not used. The unit door (see Fig. 2) was on top of the detector so that when it was open, the subassembly could be lowered into the detector from above using the overhead crane.

Normally, the active plutonium region centered in the detector, but auxiliary measurements determined axial end effects and radial position effects.

\section{B. Measurement Steps}

The measurement steps can be separated into the initial check-out and normal operation. 
TABLE I

PFR SUBASSEYBLY PLUTONIUM LOADING

\begin{tabular}{|c|c|c|c|c|c|c|c|c|c|}
\hline $\begin{array}{l}\text { Assembly } \\
\text { No. }\end{array}$ & $\begin{array}{l}\text { No. } \\
\text { Pins }\end{array}$ & $\begin{array}{l}\mathrm{Pu} \\
(\mathrm{g})\end{array}$ & $\begin{array}{c}238 \mathrm{pu} \\
(\mathrm{g}) \\
\end{array}$ & $\begin{array}{l}239 \mathrm{pu} \\
(\mathrm{g}) \\
\end{array}$ & $\begin{array}{c}240 \mathrm{pu} \\
(\mathrm{g}) \\
\end{array}$ & $\begin{array}{c}247 \mathrm{Pu} \\
(\mathrm{g}) \\
\end{array}$ & $\begin{array}{c}242 \mathrm{pu} \\
(\mathrm{g}) \\
\end{array}$ & $\begin{array}{c}240 p u(e f f) \\
(g)^{a} \\
\end{array}$ & $\begin{array}{c}239 \mathrm{pu}+241 \mathrm{Pu} \\
(\mathrm{g}) \\
\end{array}$ \\
\hline 1 & 325 & 14858.9 & 19.69 & 10953 & 3235 & 533 & 113.5 & 3475 & 11486 \\
\hline 2 & 324 & 11546.7 & 14.25 & 8582 & 2460 & 413 & $8 ! .8$ & 2634 & 8995 \\
\hline 3 & 325 & 11573.3 & 14.03 & 8621 & 2459 & 408 & 80.0 & 2626 & 9029 \\
\hline 4 & 304 & 10822.5 & 12.94 & 8046 & 2327 & 387 & 79.0 & 2492 & 8433 \\
\hline 5 & 200 & 7125 & 8.63 & 5305 & 1513 & 252 & 49.9 & 1622 & 5550 \\
\hline 6 & 148 & 5272 & 6.39 & 3926 & 1120 & 187 & 36.9 & 1200 & 4107 \\
\hline 7 & 100 & 3562 & 4.32 & 2653 & 757 & 126 & 24.9 & 871 & 2775 \\
\hline
\end{tabular}

${ }^{\mathrm{a}} 240_{\mathrm{Pu}}(\mathrm{eff}): 2.43\left({ }^{238} \mathrm{Pu}\right)+\left({ }^{240} \mathrm{Pu}\right)+1.69\left({ }^{242} \mathrm{Pu}\right)$.

1. Initial Check-out

(a) If cart is to be used in the facility, assemble detector and cart and use thumbscrews to attach detector to cart.

(b) Check out electronics as suggested in Ref. 2 and set parameters as listed in Sec. II.B.

(c) Enter the magnetic card program (labeled PRF Dounreay) in the HP-97 calculator by putting the calculator in "Run Mode" and entering "side 1" of the card with the white side up. The calculator will then display "Cre." Again enter the card "side 2" to get the full program in the HP-97.

(d) Take a 100-s count with no fuel assembly in the unit. The net coincidence rate $(R+A)-A$, where $(R+A)$ is the reals plus accidentals and $A$ is the accidental rate, should be statistically equal to zero and the totals rate $T$ should be between 200 and 2000 counts/s, depending on the amount of $\mathrm{PuO}_{2}$ in the vicinity.

(e) Position the coincidence collar around the "standard" fuel assembly. Take a longer count $(5 \times 200 \mathrm{~s})$ to deternine the fuel assembly coincidence rate.

(f) Press key $B$ to get a statisticai summary of the passive measurement as listed in Table $A-1$. 
(g) Press key $D$ to get the $240_{\text {Pu-effective mass and error (see }}$ App. A.)

(h) Compare this mass with the known value of the standard assembly and observe any significant $(\geq 1.5 \%)$ bias. See Sec. VI.A for calibration details.

2. Routine Operation

(a) Position PNCC around midsection of PFR subassembly active plutonium region.

(b) Passive mode (cadmium liner)--set time for 200-s recycle and press start button on HEC-100 electronics.

(c) After the desired number of cycles (23), press stop button on HEC-100 and program key B on HP-97. This will print out the passive results and store the data for the active assay and the mass calculation (see App. A for details).

(d) Press key D on HP-97 to get a printout of the ${ }^{240}$ Pu-effective mass and statistical error.

C. Nonroutine--Active-Mode Fissile Attribute Check

(1) Remove cadmium liner from sample cavity.

(2) Press start button on HEC-100 to start 200-s runs.

(3) After about five cycles (200 s each), stop the run and press program key $C$ on HP-97 0 print sut the active rates (see App. A). Use Figs. $B-1$ and $B-2$ to relate rates to fissile content (make necessary absorption corrections or normalize to "standard" subassembly).

(4) Use this mode only as a relative check on the fissile content.

D. Handling and Transfer Times

The time required to remove a subassembly from the detector and to bring in a new subassembly was approximately $5 \mathrm{~min}$. The controlling variable was the crane transit time.

Measurement times ranged from $10 \mathrm{~s}$ for background measurements (totals only) to overnight runs for precision and stability checks. A typical fuel subassembly measurement consisted of several runs (recycle) of $500 \mathrm{~s}$ each. 


\section{TEST RESULTS}

A. Electrical Noise and Neutron Backgrounds

Neither of these potential problems gave any trouble during the tests. No electrical noise was picked up in the equipment. The PNCC was equipped with double-braided signal cables and dry desiccant in the high-voltage junction boxes. Normal plant equipment that might have produced electrical noise was oper ting during the tests.

a neutron background from the other subasseinolies stored in the room was small ( $\sim 200$ counts/s) compared with the signal from the subassembly in the detector $(2750000$ counts $/ s)$. The neutron coincidence background was statistically zero. For comparison purposes, the totals background rate in a lightwater reactor (LWR) fuel storage area is 40-500 counts/s, depending on the proximity of the assemblies.

B. Passive Results-- 240 Pu-Efrective Mass

All the subassemblies listed in Table I were measured passively; that is, with cadmium liners in place. The run times and the measured rates are given in Table II. The coincidence rate dead-time factor is $e^{\delta T}$, where $\delta=3.0 \mu$ and $T$ is the totals rate in counts/s. For the totals rate, the dead-time factor is $\mathrm{e}^{(\delta / 3.5) T}$. These factors are somewhat larger than those used with the HLNCC $(\delta=2.4 \mu \mathrm{s})$ because the PNCC uses only four lines of electronics (preamplifier, amplifier, discriminator); whereas the HLNCC uses six amplifier lines.

Before the tests at Windscale, we measured the dead-time factors for four detector banks using ${ }^{252} \mathrm{Cf}$ and AmLi neutron sources. These measurements gave $\delta=3.0 \mu \mathrm{s}$ for the coincidence rate and $\delta / 3.5$ for the totals rate. The above factors have been included in the software program given in App. A.

The error on the dead-time correction is unimportant as long as the same factor is used for both calibration and assay, because the bias from this source cancels in the data analysis to first order.

The error listed in Table II corresponds to one standard deviation (10) considering only the counting statistics. Figure 5 graphs the results where the bottom curve corresponds to the passive-mode assay with the cadmiun in place. The errors are roughly the size of the data symbols. 
TABLE II

PASSIVE COINCIDENCE COLLAR RESULTS FOR PFR SUBASSEMBLIES

\begin{tabular}{|c|c|c|c|c|c|c|c|c|c|}
\hline $\begin{array}{l}\text { As semb ly } \\
\text { No. }\end{array}$ & $\begin{array}{l}\text { Cd } \\
\text { Liner } \\
\end{array}$ & $\begin{array}{l}\text { Time } \\
\text { (s) } \\
\end{array}$ & $\begin{array}{l}\text { D.T. } \\
\text { Corr. }\end{array}$ & $\begin{array}{l}\bar{T} \text { Corr. } \\
(\mathrm{s}-\mathrm{T})\end{array}$ & $\begin{array}{l}\bar{R} \text { Corr. } \\
(s-\bar{T}) \\
\end{array}$ & $\begin{array}{l}\sigma(R) \\
(\%) \\
\end{array}$ & $\begin{array}{c}\Delta \bar{R} \\
\left(s^{-1}\right) \\
\end{array}$ & $\begin{array}{c}\sigma(\Delta R) \\
(q) \\
\end{array}$ & $\frac{\Delta R}{T(C d)}$ \\
\hline $\begin{array}{l}1 \\
1 \\
1 \\
1\end{array}$ & $\begin{array}{l}\text { yes } \\
\text { no } \\
\text { yes } \\
\text { no }\end{array}$ & $\begin{array}{r}15 \times 4000 \\
4 \times 1000 \\
16 \times 4000 \\
3 \times 500\end{array}$ & $\begin{array}{l}1.718 \\
1.825 \\
1.723 \\
1.832\end{array}$ & $\begin{array}{l}180321 \\
200554 \\
184114 \\
201820\end{array}$ & $\begin{array}{l}6848 \\
8551 \\
6833 \\
8573\end{array}$ & $\begin{array}{l}0.25 \\
0.80 \\
0.20 \\
0.59\end{array}$ & 1739 & 2.5 & 0.944 \\
\hline $\begin{array}{l}2 \\
2\end{array}$ & $\begin{array}{l}\text { yes } \\
\text { no }\end{array}$ & $\begin{array}{l}3 \times 1000 \\
8 \times 1000\end{array}$ & $\begin{array}{l}1.528 \\
1.604\end{array}$ & $\begin{array}{l}141398 \\
157570\end{array}$ & $\begin{array}{l}4717 \\
5920\end{array}$ & $\begin{array}{l}0.54 \\
0.36\end{array}$ & 1202 & 2.2 & 0.850 \\
\hline $\begin{array}{l}3 \\
3\end{array}$ & $\begin{array}{l}\text { yes } \\
\text { no }\end{array}$ & $\begin{array}{l}4 \times 1000 \\
5 \times 1000\end{array}$ & $\begin{array}{l}1.518 \\
1.590\end{array}$ & $\begin{array}{l}139056 \\
154636\end{array}$ & $\begin{array}{l}4694 \\
5861\end{array}$ & $\begin{array}{l}0.50 \\
0.41\end{array}$ & 1167 & 4.4 & 0.839 \\
\hline $\begin{array}{l}4 \\
4\end{array}$ & $\begin{array}{l}\text { yes } \\
\text { no }\end{array}$ & $\begin{array}{r}16 \times 4000 \\
4 \times 1000\end{array}$ & $\begin{array}{l}1.504 \\
1.577\end{array}$ & $\begin{array}{l}136167 \\
151775\end{array}$ & $\begin{array}{l}440 ? \\
5552\end{array}$ & $\begin{array}{l}0.25 \\
0.44\end{array}$ & 1150 & 1.6 & 0.844 \\
\hline $\begin{array}{l}5 \\
5\end{array}$ & $\begin{array}{l}\text { yes } \\
\text { no }\end{array}$ & $\begin{array}{l}7 \times 1000 \\
4 \times 500\end{array}$ & $\begin{array}{l}1.283 \\
1.319\end{array}$ & $\begin{array}{l}83320 \\
32220\end{array}$ & $\begin{array}{l}2395 \\
2889\end{array}$ & $\begin{array}{l}0.43 \\
0.68\end{array}$ & 493.6 & 3.9 & 0.592 \\
\hline $\begin{array}{l}6 \\
6\end{array}$ & $\begin{array}{l}\text { yes } \\
\text { no }\end{array}$ & $\begin{array}{l}3 \times 500 \\
3 \times 500\end{array}$ & $\begin{array}{l}1.204 \\
1.227\end{array}$ & $\begin{array}{l}61886 \\
68212\end{array}$ & $\begin{array}{l}1631 \\
1922\end{array}$ & $\begin{array}{l}0.90 \\
0.8 ?\end{array}$ & 290.9 & 6.6 & 0.470 \\
\hline $\begin{array}{l}7 \\
7\end{array}$ & $\begin{array}{l}\text { yes } \\
\text { no }\end{array}$ & $\begin{array}{l}4 \times 500 \\
6 \times 500\end{array}$ & $\begin{array}{l}1.134 \\
1.148\end{array}$ & $\begin{array}{l}42046 \\
46115\end{array}$ & $\begin{array}{l}1023 \\
1196\end{array}$ & $\begin{array}{l}0.94 \\
0.74\end{array}$ & 173.0 & 6.8 & 0.411 \\
\hline $\begin{array}{l}1 A^{a} \\
1 A^{a}\end{array}$ & $\begin{array}{l}\text { yes } \\
\text { no }\end{array}$ & $\begin{array}{l}2 \times 500 \\
2 \times 300\end{array}$ & $\begin{array}{l}1.791 \\
2.046\end{array}$ & $\begin{array}{l}194332 \\
238642\end{array}$ & $\begin{array}{r}8074 \\
14156\end{array}$ & $\begin{array}{l}0.40 \\
0.65\end{array}$ & 6082 & 1.4 & 3.13 \\
\hline
\end{tabular}

aAssembly $1 A$ is the same as No. 1, but the detector sides on the collar are moved into BWR geometry $(16.5 \mathrm{~cm}$ apart $)$.

A measurement time of $1000 \mathrm{~s}$ gave a statistical error $(1 \sigma)$ of $20.75 \%$. For more routine verification work, a 300-s run would be adequate with a standard deviation of $27.5 \%$.

\section{Active Results--Plutonium Fissile}

When the cadmium liners are removed, the returning reflected thermal neutrons give a response proportional to the total fissile content in the subassembly. The upper curve in Fig. 5 corresponds to the measurements with no cadmi um liners, and thus the difference in the two curves $(\Delta R)$ is proportional to the fissile loading. For example, if there were no fissile material in the assembly, the two curves would overlap and $\Delta R$ would go to zero. 
Because this is a new experimental technique it was not included in the present test and evaluation. These results are in App. B for interested readers.

D. Radial and End Effect Results

Shifting the PFR subassembly from the center of the cavity to the side (touching) increased the coincidence rate of only $2-3 \%$. Because this shift is large $(3-4 \mathrm{~cm})$, the normal variations in radial positioning should be $<1 \%$. This was consistent with the results for repeat measurements on a subassembly after repositioning.

As the detector nears the plutonium region boundary, the neutron coincidence rate drops off because of neutron leakage and less plutonium in the detector. To measure this effect, we moved the PNCC head from the center of the plutonium region to distances past the end of the plutonium in increments of $10 \mathrm{~cm}$ each. Figure 6 shows the results of these measurements. The primary conclusions are that the top (or bottom) of the detector head should remain at least $15 \mathrm{~cm}$ inside the plutonium region to be free of end effects. Conversely, the unit can locate the approximate end pints of the plutonium region.

\section{E. In-Plant Precision and Stability}

Several long runs (overnight) checked the stability and precision of the system. Cyclic runs were taken on each assembly and compared with the counting statistical error determined from

$$
\sigma=\frac{\sqrt{(R+A)+A}}{R} \times 100 \%
$$




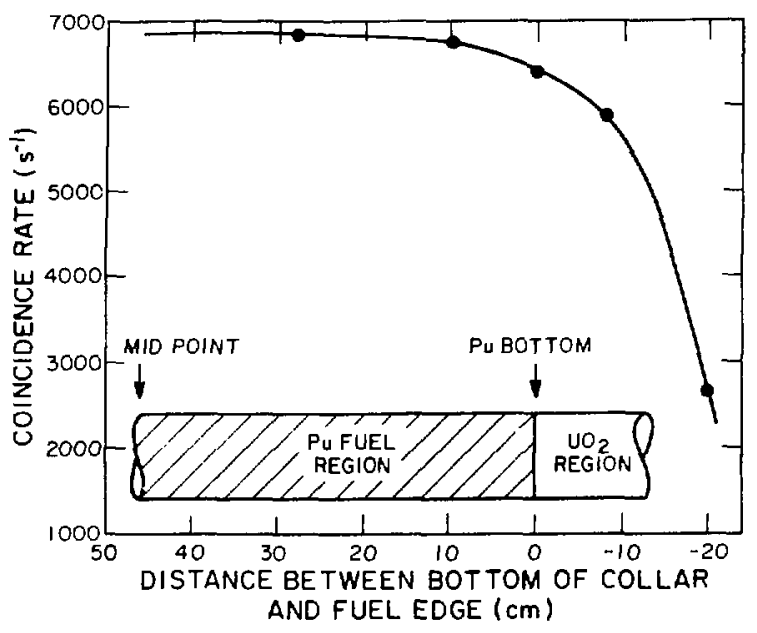

Fig. 6.

Coincidence rate near the end of the MOX fuel region in a PFR subassembly.

This quantity compares with the standard deviation of the observed scatter about the mean $(S)$ in the coincidence rate that is calculated automatically in the program given in App. A.

Table III lists the results of the tests and the excellent agreement in $\sigma$, and $S$ indicates no problems from electrical noise or instabilities.

TABLE III

IN-PLANT STABILITY AND PRECISION TESTS

Subassembly

No.

1

4

1
Run Time

(s)

$15 \times 4000$ (overnight)

$16 \times 4000$ (overnight)

$16 \times 4000$ (overnight)
Standard Deviation

Estimated (10) Observed (S)

$0.37 \%$

$0.36 \%$

$0.37 \%$

$0.35 \%$

$0.37 \%$

$0.26 \%$

\section{CALIBRATION}

A. Plutonium-240 Effective Mass

The data given in Table II were fit by both a quadratic function and a power function. The quadratic function did not give a good fit for the lowmass data, so it was abandoned in favor of a power function of the form 


$$
M_{240}=5.00 R^{0.741},
$$

where $M_{240}$ is the $g$ 240 Pu-effective and $R$ is the average net coincidence rate after the dead-time correction. This value is calculated automatically in the software program (App. A) by pressing key $D$ on the HP-97 calculator.

Table IV gives the results of the measurements when Eq. (2) is used to calculate the $M_{240^{\circ}}$. The average difference between the relative measured values and the given masses was $1.2 \%$. This basically measures the data scatter about the calibration function. The fit in the mass region from 10 to $14 \mathrm{~kg}$ is considerably better than the average value. These results are remarkably good, considering the different geometries involved in the partially loaded subassemblies.

TABLE IV

PASSIVE NEUTRON ASSAY RESULTS FOR PFR SUBASSEMBLIES

\begin{tabular}{|c|c|c|c|c|}
\hline $\begin{array}{l}\text { As sembly } \\
\text { No. }\end{array}$ & $\begin{array}{c}240 \mathrm{Pu}-\mathrm{Eff} . \\
\mathrm{Tag}(\mathrm{g}) \\
\end{array}$ & $\begin{array}{l}\bar{R} \text { Corr. } \\
\left(\mathrm{s}^{-1}\right) \\
\end{array}$ & $\begin{array}{c}\text { Assay }^{\mathrm{a}} \\
\left(\mathrm{g}^{240} \mathrm{Pu} \text {-Eff.) }\right) \\
\end{array}$ & $\frac{\text { Assay-Tag }}{\text { Tag }} \times 100 \%$ \\
\hline 1 & 3475 & 6848 & 3476 & $+0.03 \%$ \\
\hline 1 & 3475 & 6833 & 3471 & $-0.12 \%$ \\
\hline 2 & 2634 & 4717 & 2637 & $+0.11 \%$ \\
\hline 3 & 2626 & 4694 & 2628 & $+0.08 \%$ \\
\hline 4 & 2492 & 4402 & 2505 & $+0.52 \%$ \\
\hline 5 & 1662 & 2395 & 1596 & $-4.07 \%$ \\
\hline 6 & 1200 & 1631 & 1200 & $+0.00 \%$ \\
\hline 7 & 811 & 1023 & 850 & $+4.80 \%$ \\
\hline
\end{tabular}

$\mid$ Ave $\mid=1.22 \%$

\footnotetext{
aRelative assay values obtained from calibration function $M=5.00 R^{0.74}$ (cadmi um 1 iner).
} 
No ${ }^{252}$ Cf or AmLi normalization source was provided with the PNCC, so future use of Eq. (2) will depend on the electronic system stability or the renormalization to a "standard" assembly at the PFR reactor facility. If renomalization is required, it should only affect the coefficient (5.00) in the calibration function.

B. Example of ${ }^{240} \mathrm{Pu}-$ Effective Mass Calculation

After the PNCC is transferred from Windscale to Dounreay, it may be necessary to renormalize the calibration function using a "standard" PFR subassembly. This reference subassembly should remain available between visits to the facility.

Calculation Example (Hypothetical Data)

(a) Assume standard subassembly with

$$
240 \mathrm{Pu} \text {-effective }=2700 \mathrm{~g} \text { (given) }
$$

(b) Measure $\bar{R}=4950\left(s^{-1}\right)(5 \times 200-s$ runs for standard subassembly $)$ Press key $D ; M=2733 \mathrm{~g}$, from $M=5.00 \mathrm{R}^{0.741}$.

(c) $M($ corr. $)=M($ meas $) \times(2700 / 2733)$

$$
=M(\text { meas }) \times(0.988) \text {. }
$$

Therefore, reduce al1 assay masses (from key D) by a factor of 0.988 for this measurement period.

\section{Multiplication}

Because of the large plutonium mass in the PFR subassemblies, the neutron multiplication effect is large. The calibration curves given in Fig. 5 include this multiplication, and they can be used to assay other assemblies so long as the $(\alpha, n)$ and fissile-to-fertile ratio characteristics of the fuel do not change appreciably. One problem with this assumption is that the ${ }^{241} \mathrm{~m}$ content builds up with time giving more $(\alpha, n)$-related multiplication.

Future analyses will correct for multiplication using the totals/coincidence ratio method of Ensslin. ${ }^{3}$ Also, a new technique of using $\Delta R / T$ to predict the multiplication in the fissile material is being investigated. 
A. Accuracy for $240 \mathrm{Pu}-$ Effective Mass

The statistical precision for the coincidence counting of ${ }^{240} \mathrm{Pu}$-effective is $0.75 \%(1 \sigma)$ for a $1000-s$ count. Because the mass is related to the counting rate $R$ by the function $M=5.00 R^{0.741}$, the deviation in $M$ is less than the deviation in $R$. For example, a $1 \%$ change in $R$ in the vicinity of 325 pins ( 26000 counts/s) results in only a $0.74 \%$ change in $M$.

For actual PFR subassemblies, variations in plutoni'sm isotopics and $241 \mathrm{Am}$ will likely cause more error than the counting statistics, so shorter measurement intervals can be used to reduce verification time.

B. Neutron Backgrounds and Electrical Noise

Room background neutron levels in the subassembly fabrication area were much lower ( $\left.21200 \mathrm{~s}^{-1}\right)$ than the signal rates $\left(2150000 \mathrm{~s}^{-1}\right)$. Several subassemblies were stored near the measurement station.

No electrical noise problems were observed during the exercise.

C. Precision and Stability

In the long-interval cyclic measurements, an observed scatter about the mean was approximately equal to the standard deviation calculated from the counting statistics. This value was $0.37 \%(1 \sigma)$ for a $4000-s$ run.

D. Accuracy for ${ }^{239} \mathrm{Pu}+241 \mathrm{Pu}$

These preliminary measurements were quite successful in evaluating the use of $\Delta R$ and $\Delta R / T$ to determine the total fissile content. The statistical error in obtaining $\Delta R$ was relatively large $(27 \%)$ owing to the poor sample-detector geometric coupling. Because of the statistical error and the time required for the technique, we recommend that the method be used only for the present as an occasional attribute check on the fissile content.

Note that the measurements of PFR subassemblies at Dounreay will be performed with subassemblies inside steel storage canisters. Thermal-neutron absorption in the steel reduces the value of $\Delta R$ by about 5-10\% from that measured at windscale with no storage canisters. 
The technique of using $\Delta R / T$ to determine the fissile content is easier to apply for LWR-MOX fuel assemblies that have no thermal-neutron absorbers in the cladding.

E. Recommendations

(1) Use several cycles (3-5) of $200 \mathrm{~s}$ each for the verification measurements.

(2) For routine operation, leave the cadmium liners in the detector.

(3) Establish one subassembly as a "standard" and refer to it for different verification exercises.

(4) Use the Windscale calibration function $M=5.00 R^{0.741}$ and only change the normalization coefficient $(5.00)$ if a bias is present.

(5) This calibration function and the coefficients have been written into the HP-97 software program listed in App. A (subroutine D).

(6) Additional calculations and measurements will be required for the universal FBR detector to extend the calibration over the full range of LMFBR subassemb1ies. 


\section{APPENDIX A}

\section{DATA COLLECTION AND STATISTICAL ANALYSES FROGRAM}

USING THE HP-97 CALCULATOR

A software program was written and tested during the exercise at Windscale. The purpose of the program was to collect data in the cyclic mode; to calculate the estimated standard deviation,

$$
\sigma \%=\frac{\sqrt{(R+A)+A} \times 100 \%}{R}
$$

as well as the mean responses, $T$ and $R$, the dead-time correction factors, and the obseryed scatter (S), about the mean. At the end of $n$ runs (or cycles), the standard deviation for the total counting time is calculated from

$$
\frac{\sigma_{o}}{\sqrt{n}}
$$

after making the dead-time corrections.

The inspector has a comparison of

$\sigma \%$ (predicted deviation)

with

S\% (observed scatter)

at the time of the measurerients.

In the program, subroutine $B$ is used for the passive measurenent. The passive coincidence results are stored for use in subroutine $C$, which is used 
for the active measurement. The background and dead-time correction factors are directly written into the program and no entries are required from the user. These values should not be changed as long as the present calibration constants are in use. An example of the readout format is given in Table A-1. The HP-97 program that includes the 240 Pu-effective mass calculation using the function $M=5.00 R^{0.741}$ is given in Table A-2.

In summary:

Key $B \rightarrow$ passive assay data and error printout,

Key $\mathrm{C}+$ active assay data and error printout,

Key $D \rightarrow$ mass (g 240 Pu-effective), and

Key $\mathrm{E} \rightarrow$ clear statistics.

The program listing and explanation of the HP-97 Data Collection and Statistical Analyses Program are given in Table A-2. 
TABLE A-1

DATA READOUT FORMAT FOR HP-97 DATA COLLECTION PROGRAM FOR A PFR ASSEMBLY

Passive Mode (Cd)

\begin{tabular}{|c|c|c|}
\hline $\begin{array}{r}1000 \\
138673 \\
618437 \\
615351 \\
3080 \\
1.14 \\
1.00\end{array}$ & $\begin{array}{l}\star \star \star \\
\star \star \star \\
\star \star \star \\
\star \star \star \\
\star \star \star \\
\star \star \star \\
\star \star \star\end{array}$ & $\begin{array}{l}- \text { time (s) } \\
-T / S \\
-(R+A) / S \\
-A / s \\
=R / s \\
-\sigma \% \\
-n\end{array}$ \\
\hline $\begin{array}{r}1000 \\
138687 \\
678560 \\
165508 \\
615508 \\
3051 \\
1.15 \\
2.00\end{array}$ & $\begin{array}{l}\star \star \star \\
\star \star \star \\
\star \star \star \\
\star \star \star \\
\star \star \star \\
\star \star \star \\
\star \star \star \\
\star \star \star\end{array}$ & 2nd run \\
\hline $\begin{array}{r}1000 \\
139215 \\
623303 \\
620178 \\
3124 \\
1.12 \\
3.00\end{array}$ & $\begin{array}{l}\star \star \star \\
\star \star \star \\
\star \star \star \\
\star \star \star \\
\star \star \star \\
\star \star \star \\
\star \star \star\end{array}$ & 3rd run \\
\hline
\end{tabular}

Press B $\rightarrow$

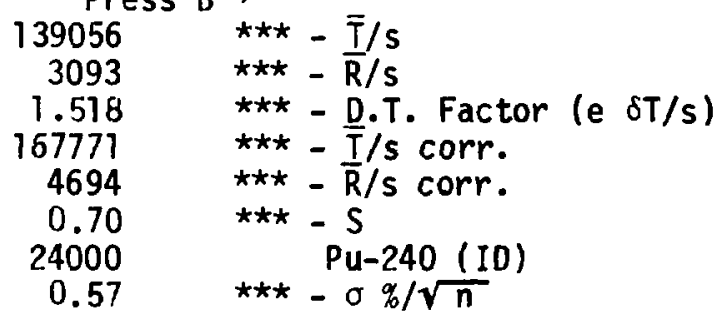

2627.7

14.9

Press $0 \rightarrow$

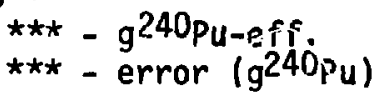

Active Mode (no Cd)

\begin{tabular}{|c|c|}
\hline $\begin{array}{r}1000 \\
154581 \\
768367 \\
764625 \\
3742 \\
1.05 \\
1.00\end{array}$ & 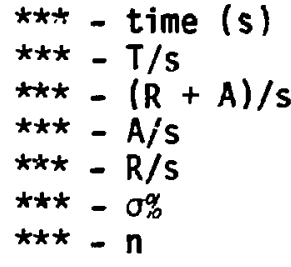 \\
\hline $\begin{array}{r}1000 \\
154606 \\
768535 \\
764865 \\
3670 \\
1.07 \\
2.00\end{array}$ & $\left.\begin{array}{l}\star \star \star \\
\star \star \star \\
\star \star \star \\
\star \star \star \\
\star \star \star \\
\star \star \star \\
\star \star \star \\
* \star\end{array}\right\}$ \\
\hline
\end{tabular}

$\left.\begin{array}{rl}1000 & \star \star \star \\ 154641 & \star \star \star \\ 763929 & \star \star \star \\ 765236 & \star \star \star \\ 3692 & \star \star \star \\ 1.06 & \star \star \star \\ 3.00 & \star \star \star\end{array}\right\}$ 3rd run

$\left.\begin{array}{rl}1000 & \star \star \star \\ 154667 & \star \star \star \\ 769113 & \star \star \star \\ 765504 & \star \star \star \\ 3609 & \star \star \star \\ 1.09 & \star \star \star \\ 4.00 & \star \star \star\end{array}\right\}$ 4th run

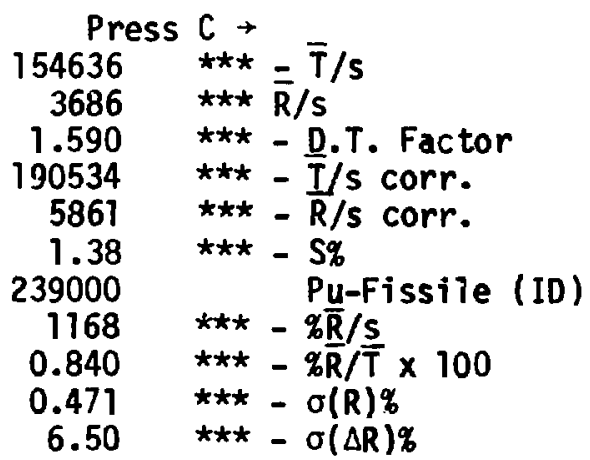


TABLE A-2

HP-97 PROGRAM FOR PFR SUBASSEMBLIES

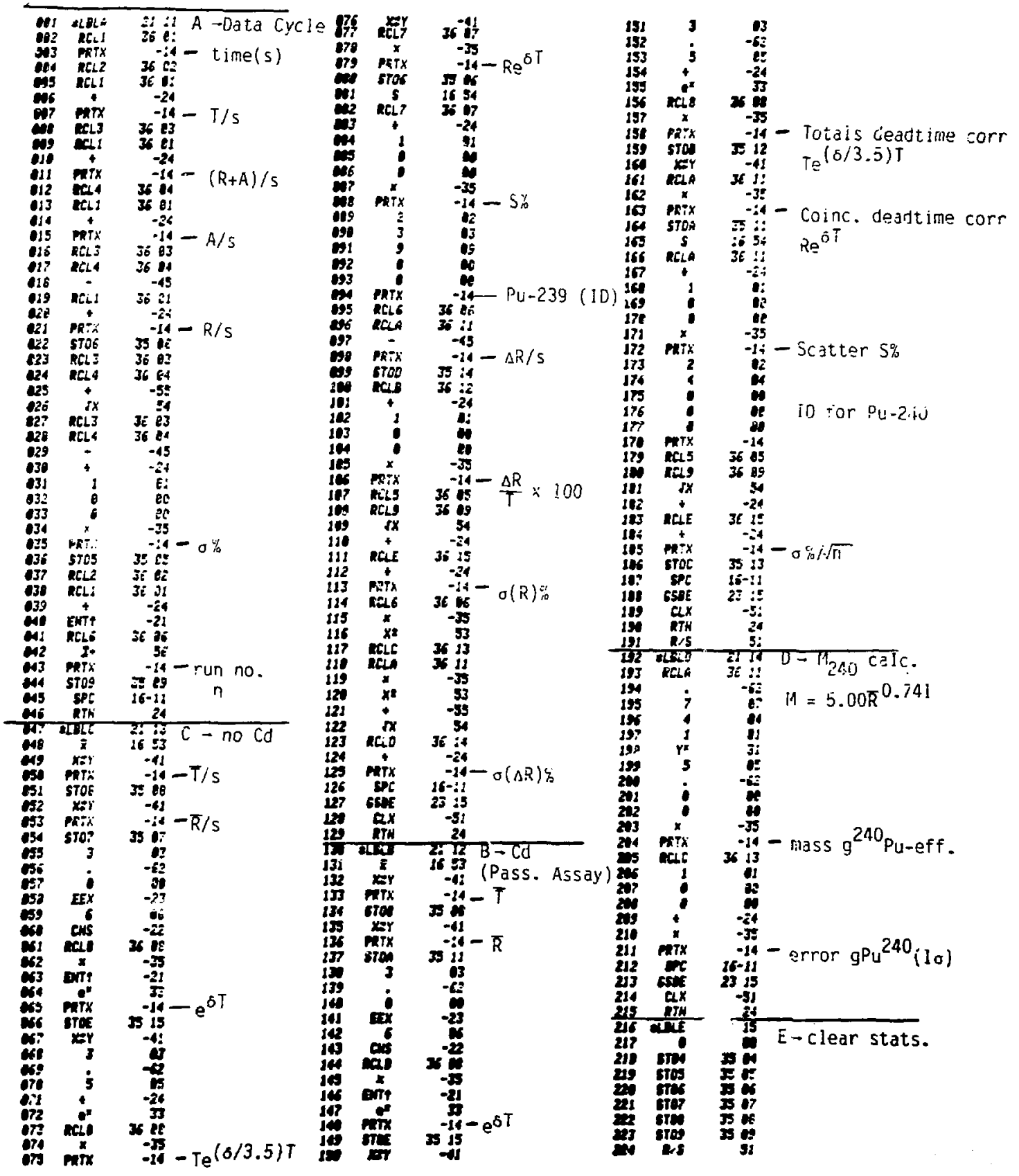


APPENDIX B

PASSIVE/ACTIVE MODE ASSAY

During the measurements on the PFR subassemblies, we evaluated a new selfinterrogation technique that measures the fissile content in the samples. The active-mode assay is based on the principle of self-interrogation by reflected passive neutrons. The neutrons originate from $(\alpha, n)$ reactions on the oxygen and possible containinants, spontaneous fission from the even isotopes of plutonium $\left({ }^{238} \mathrm{Pu}+{ }^{240} \mathrm{Pu}+{ }^{242} \mathrm{Pu}\right)$, and multiplication neutrons resulting primarily from fissile material in the assembly.

Both the coincidence rate $R$ and the totals rate $T$ are measured with and without the cadmium sheet. The normal passive-mode calibration curve corresponds to $R$ vs ${ }^{240} \mathrm{Pu}$-effective mass. The induced fission rate from the reflected neutrons is given by

$$
R \text { íno } C d)-R(C d) \equiv \Delta R \quad \text {. }
$$

However, the value of the induced coincidence counts is alsc proportional to the neutron source strength, which is different for each sutassembly. To normalize the source strength out of the response function, divide by $T$ to obtain the respoise ratio $\Delta R / T$, which is proportional to the fissile content independent, of the source strength through a calibration curve.

The measured values of $\triangle R$ and $\triangle R / T$ for the PFR subassemblies are listed in Table II. Figure $B-1$ shows a graph of $\Delta R$ for the different plutonium loadings in the subassemblies, and Fig. B-2 shows the same data after dividing by the total rate $T(C d)$.

The PFR subassemblies are "black" or saturated to the themal-neutron interrogation, which would result in a flat response curve. However, there is significant fast neutron multiplication of the fission neutrons to give the slope in the curve shown in Fig. B-2. The shape of this curve is similar to the response curves for PWR and BWR fuel assemblies when using the Coincidence Collar in the active (thermal neutron) mode. ${ }^{4}$ The neutron coincidence counting is important because it amplifies the multiplication response. For example, a 


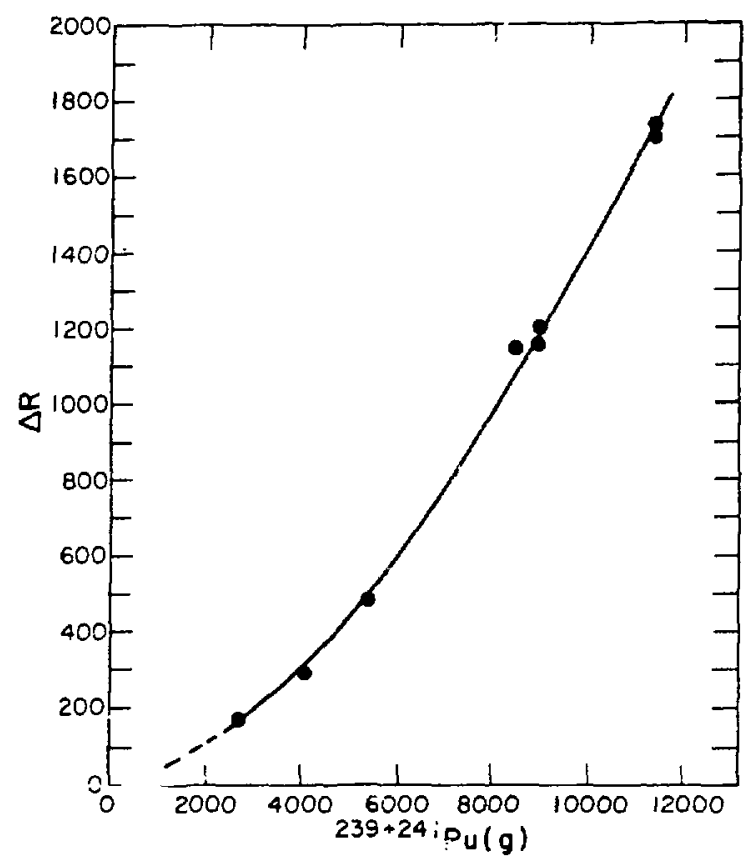

Fig. B-1.

Plot of $\Delta$, which is the difference in the response without and with cadmium vs plutonium fissile content in PFR subassemblies.

Fig. B-2.

Plot of $\triangle R / T$, which is the induced fission coincidence rate per source neutron vs plutonium fissile content.

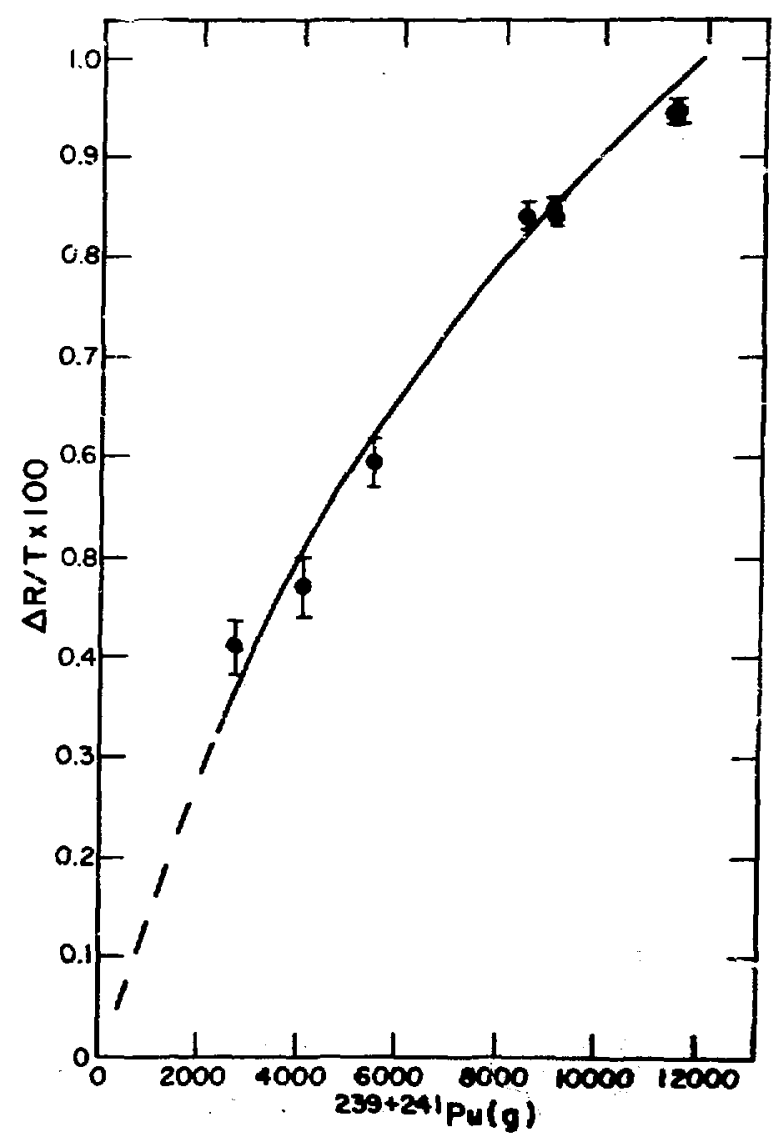


normal spontaneous fission event has a $\bar{v}$ (averäge number of neutrons per fission) of about 2.2, whereas the induced fissions from reflected spontaneous fission neutrons have an effective $\bar{v}$ of $23.6(2.2-1+2.4)$ for the coincidence time gate. The coincidence count rate is much more sensitive to the average value of $\bar{v}$ than the totals rate.

To check the penetrability of the technique using a mockup LWR assembly at Los $A 1$ amos, 10 rods were removed from the perimeter and $\Delta R / T$ was measured. These rods were then replaced and 10 rods were removed from the central section of the assembly. The values of $\Delta R / T$ were the same within a statistical precision of a few per cent.

The statistical error connected with the measurement of $\Delta R / T$ is $27 \%(1 \sigma)$ in $1000 \mathrm{~s}$, which is larger than desired. The primary problem for the present experiments on PFR subassemblies was the poor coupling between the sample and the detector head. That is, only a small fraction of the reflected neutrons return into the fuel assembly. A measure of this return fraction is the "signal/background" ratio $\triangle R / R(C d)$. For the normal geometry with the PNCC and the PFR subassemblies, inis ratio was 20.25 ; however, for one measurement (run 1A, Table II) we collapsed the size of the PNCC sample cavity so that the sides were almost in contact with the PFR hexagonal box. In this: case, the ratio of $\Delta R / R$ increased to 0.75 and the statistical error in $\Delta R$ was reduced by a factor of $\approx 3$.

In the future design of a universal detector head for measuring FBR subassemblies, the geometric coupling would be good and the statistical uncertainties in determing $\Delta R$ would not be a severe problem in measuring the fissile content.

In surmary, the self-interrogation method gives the reactivity of the fuel assembly, which is primarily a function of the fissile content for a given sample-moderator configuration such as a fuel assembly. For FBR subassemblies, the combination of the active fissile determination with the passive-mode ${ }^{238} \mathrm{Pu}+{ }^{240} \mathrm{Pu}+{ }^{242} \mathrm{Pu}$ measurement verifies more completely the totai plutonium content.

\section{REFERENCES}

1. H. 0. Menlove, "Passive/Active Coincidence Collar for Total Plutonium Measurement of MOX Fuel Assemblies," Los Alamos National Laboratory report LA-9288-MS (ISPO-170)(1982). 
2. M. S. Krick and H. 0. Menlove, "High-Leve1 Neutron Coincidence Counter (HLNCC)," Los Alamos Scientific Laboratory report LA-7779-M (ISPO-53) (June 1979).

3. M. S. Krick, "Neutron Multiplication Corrections for Passive Thermal Neutron Wel1 Counters," Los Alamos Scientific Laboratory report LA-8460-MS (1980), pp. 59-62.

4. Howard 0. Menlove, "Description and Performance Characteristics for the Neutron Coincidence Collar for the Verification of Reactor Fuel Assemblies," Los Alamos National Laboratory report LA-8939-MS (ISP0-142) (1981). 


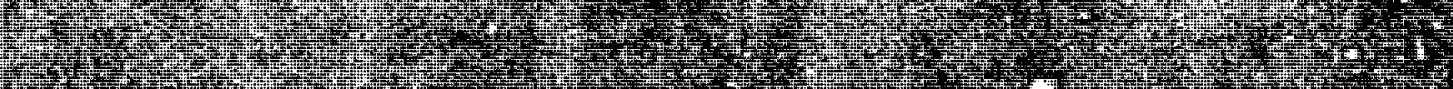

-

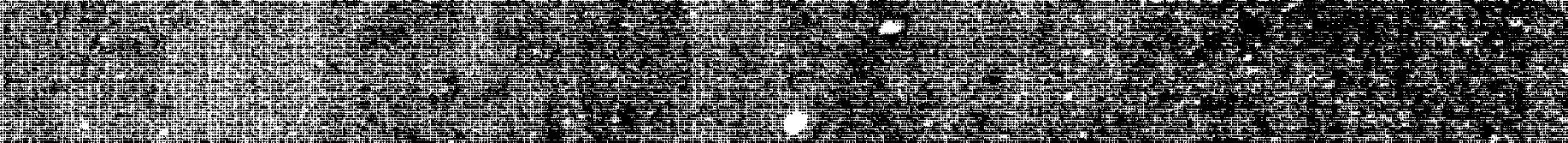

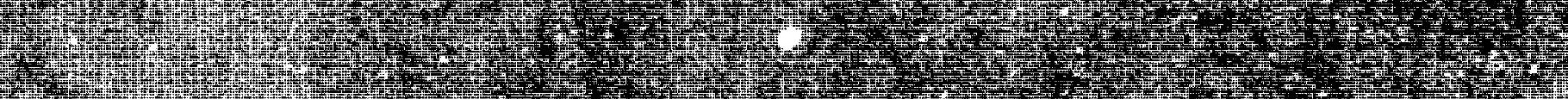
4ty

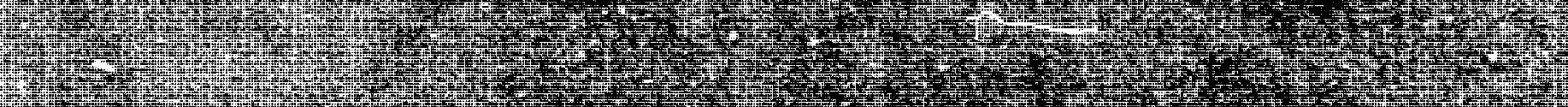

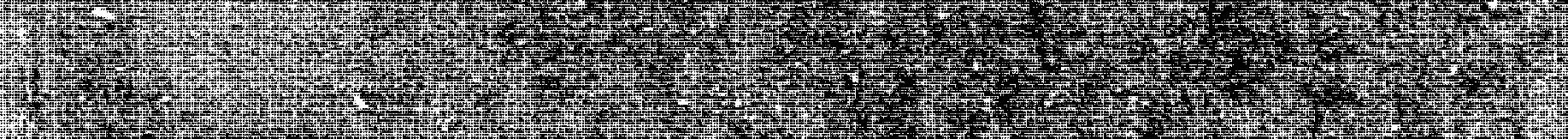
Hy

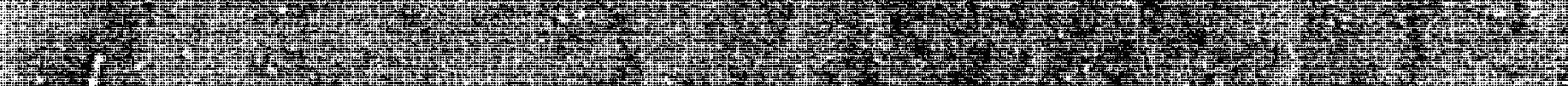

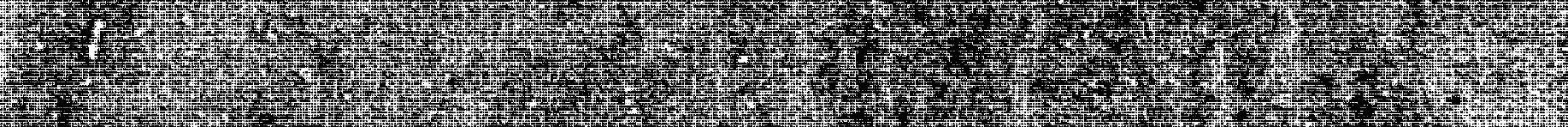
15y

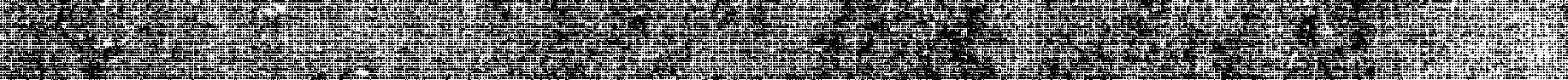

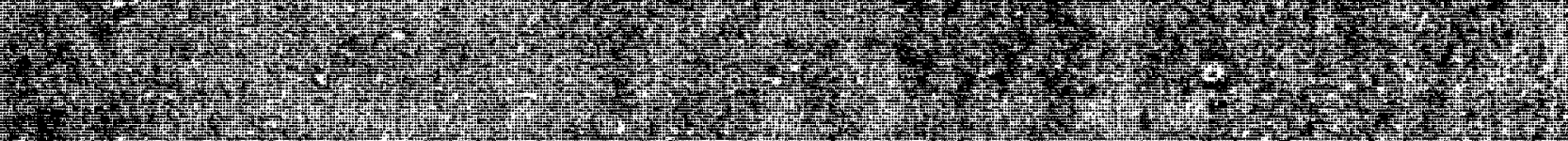

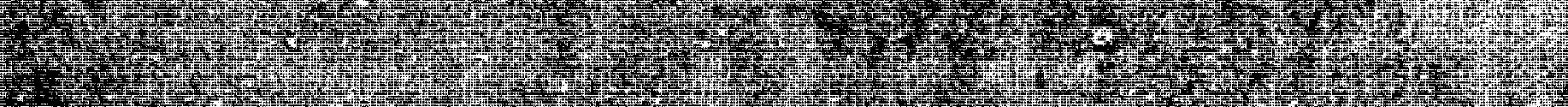
W Fy

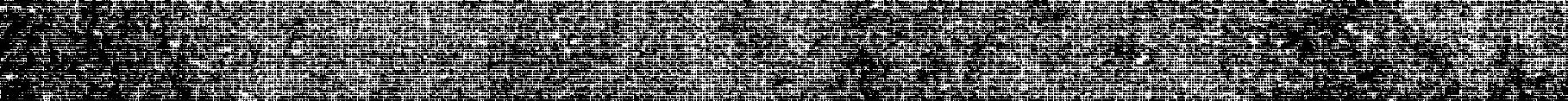
W P.

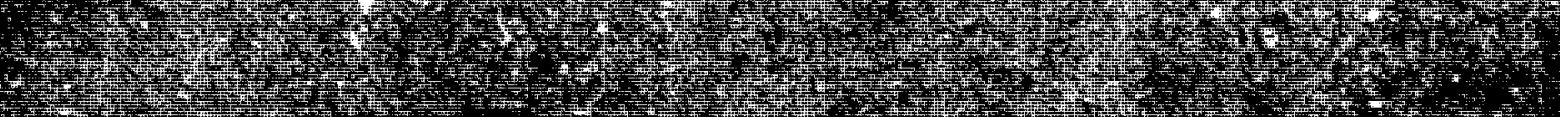

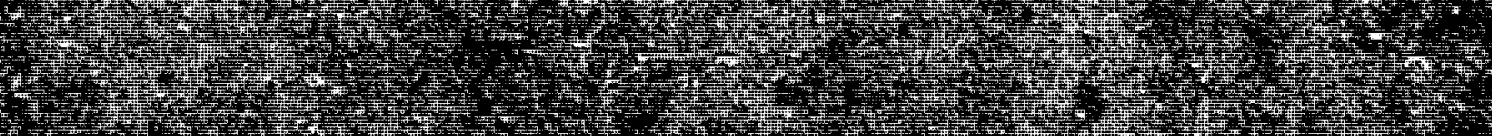

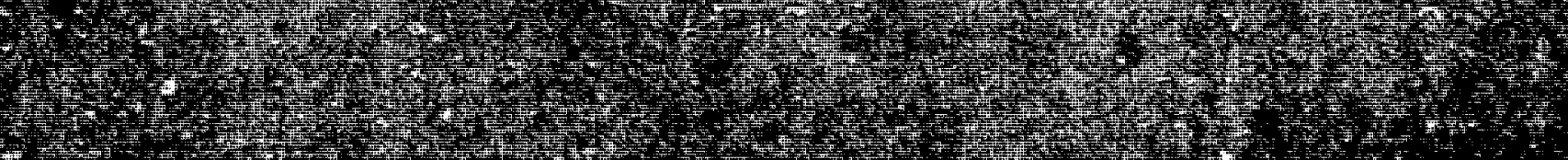
Pats
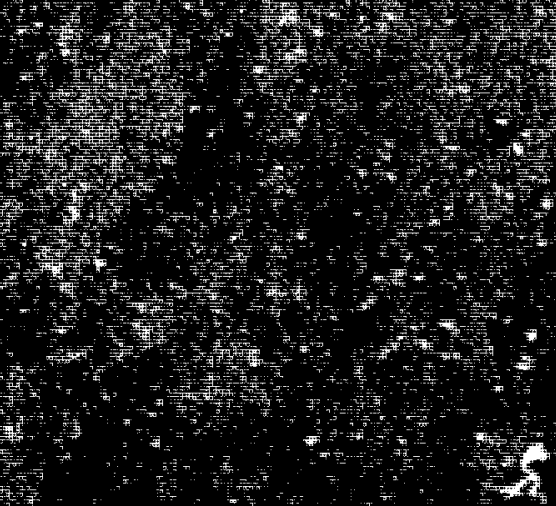

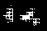

